\title{
Differentiating African and Western Feminisms through Room Symbolism
}

\author{
André Kaboré \\ Department of Anglophone Studies, Université Ouaga I Pr. Joseph Ki-Zerbo, Burkina Faso
}

Copyright $\subseteq 2017$ by authors, all rights reserved. Authors agree that this article remains permanently open access under the terms of the Creative Commons Attribution License 4.0 International License

\begin{abstract}
The current study is a comparative analysis of the room symbolism in some Western and African feminist writings, such as Virginia Woolf's A Room of One's Own, Monique Ilboudo's 'Le féminisme au Burkina Faso: mythes et réalités?', and Chimamanda Ngozi Adichie's We Should all be Feminists. Thus, this paper tries to shed light on these female writers' projections of feminism by 'decoding' the room images found in their works and by making comparative projections that demonstrate the necessity to make a distinction between African and Western feminisms.
\end{abstract}

Keywords Feminism, Room, Interpretative Community, Westernization, Gender Identity

\section{Introduction}

Virginia Woolf, in her essay, A Room of One's Own (1929), quotes Professor Trevelyan's History of England which tells of women being "locked up, beaten and flung about the room, without any shock being inflicted on public opinion," of marriage being "not an affair of personal affection, but of family avarice," of betrothal often taking place "while one or both of the parties was in the cradle" [1, p35]. All these practices were common place in about 1470 and was done to the approval of public opinion.

Similarly, the Nigerian woman writer, Chimamanda Ngozi Adichie, in her non-fiction work, We Should All Be Feminists (2014), evokes a similar treatment of women in her country, namely of a young woman being gang-raped in a Nigerian university. She is outraged that "the response of many young Nigerians, both male and female, was something like this: 'Yes, rape is wrong, but what is a girl doing in a room with four boys?"' [2, p32]. She regrets that "Nigerians have been raised to think of women as inherently guilty," and "to expect so little of men that the idea of men as savage beings with no self-control is somehow acceptable." [2, p33]. Adichie, like Chielozona Eze, is part of the third-generation African women writers who "believe that gender equality in most African societies has not yet been realized" [3], as many African women are still valued through the lenses of traditional cultures than as individuals with proper rights, wishes and dignities.

Monique Ilboudo too, a woman writer from Burkina Faso, in "Le féminisme au Burkina Faso: mythes et réalités?" (2007) tells how Moose women used pseudonyms as a system to survive against men's home misconduct that was publicly accepted [4, p165-175]. In addition, she underlines that prior to the enforcement of new laws advocating equality between man and woman, girls were even given to marriage before they came out of their mothers' wombs - their pre-natal rooms - in the following way, "if my wife gives birth to a girl, it is yours." [4, p171].

These three contexts of ill-treatment of women, all happening in connexion with rooms, a complex symbol representative of the individual, and the three outrageous public reactions are all similar, though they tell us nothing significant about the room other than a place of human habitation. Yet, I want to underline that through these room-connected examples of women's ill-treatment, these women writers are fighting for positive change in women's conditions of life.

Both Adichie and Ilboudo are contemporary African writers and are familiar with Woolf's works. For example, Adichie's new short story, "The arrangements," commissioned by and for The New York Times Book Review is a tribute to Virginia Woolf's Mrs. Dalloway, a novel that is especially notable for being told from the perspective of a woman. Yet, if they all fight for women to have rooms of their own, the understanding of the nature and specificities of that room is what makes the difference. As they are from different continents, cultural differences bring about differences in the meanings of symbols which change from one community to another; hence different feminisms.

This paper explains the room symbolism in some of Virginia Woolf's, Monique Ilboudo's and Chimamanda Ngozi Adichie's writings. What does "room" represent for each of them? What is the impact of these representations 
on their feminisms? In which aspects are these feminisms similar or different?

The discussion will be carried out around the symbolism of "room" to which Woolf and Ilboudo resort in their feminist fights. Adichie does not explicitly use this symbolism, yet her feminism constitutes a bridge between the two. This paper sheds light on these female writers' projections of feminism by "decoding" the room images found in their works and by making comparative projections that demonstrate the necessity to make a distinction between African and Western feminism. The analysis will be done from the perspective of an African interpretive community, resorting to works by other women writers, some of whom do not want to be called "feminists".

\section{Materials and Methods}

Stanley Fish's theory of interpretive communities and feminist theory will be used. Interpretive communities consist of a group of readers who share the same conventions for understanding literary works in certain ways. In his essay, "Interpreting the Variorum", Stanley Fish declares that "interpretive communities are made up of those who share interpretive strategies not for reading (in the conventional sense) but for writing texts, for constituting their properties and assigning their intentions" $[5, \mathrm{p} 219]$. In other words, meaning in a text comes from the readers' perception about the world or that of their various interpretive communities about the universe. Refuting the claim that one reads a text before interpreting it, Fish maintains that "interpretive strategies are not put into execution after reading (...), they are the shape of reading, $(\ldots)$, they give texts their shape, making them rather than, as it is usually assumed, arising from them." [5, p218]. In making this comment, Fish asserts that the act of reading and the act of interpreting are one in the same.

According to this theory, a work of art or symbol does not exist objectively and independently of any experience of it, but is the reader's experience [6, p123]. Fish says that there is always a hermeneutic gap between the linguistic elements a text contains and the stylistician's interpretation of them [7]. This theory supports the fact that every piece of literature has no meaning on its own; the readers hold supremacy as their experience with a text determines its truth.

With this concept of interpretive communities, Fish also argues that the informed reader's interpretive perceptions and aesthetic judgments are not idiosyncratic but socially constructed, depending heavily on the assumptions shared by the social group to which the reader belongs. It means that the various interpretive communities are constantly being changed and shaped by conventions such as one's education, family, friends, or religion and so can be shared with other people.
Thus, these female writers' cultural and educational backgrounds place them in different interpretive communities. The importance that each interpretive community gives to the room symbolism in relation to their perception of female characters will be compared to standard Western understanding of feminism.

I will also use feminism as a theory. I agree with Stevi Jackson and Jackie Jones [8, p1] when they say that "feminist theory seeks to analyse the conditions which shape women's lives and to explore cultural understandings of what it means to be a woman." It is hoped that these two methods may help to unravel the complexities and innuendos of room symbolism in feminism.

\section{Results, Analysis and Discussion}

\subsection{A Cross-Reading of Room Symbolism in Western and African Cultures}

In both Western and African cultures, at the time preceding the birth of the writers under consideration, girls had no private rooms in their parents' compounds. Woolf [1, p44] for instance writes that, in the past, for a girl, "to have a room of her own, let alone a quiet room or a soundproof room, was out of the question, unless her parents were exceptionally rich or very noble." She underlines here the poverty of families at that time. Later, addressing women in her audience, Woolf $[1, \mathrm{p} 47]$ further says, "it is all very well for you, who have got yourselves to college and enjoy sitting-rooms ... of your own" to show that women's situation pertaining to having personal rooms has changed over time. But poverty does not seem to be the real and only cause in the past since boys had private rooms and girls had none, especially in Moose and Igbo societies in Burkina Faso and Nigeria where Ilboudo and Adichie are respectively from. In fact, the situation at this historical period in the West is similar in the African context, namely the Burkinabe one, as powerfully described by the Burkinabe feminist writer Monique Ilboudo:

In Moose people's customs for example, the word roogo (room) has a double meaning. It means at the same time "room" and "family", nay marriage, but only while referring to woman. Traditionally, the young girl has no roogo in her father's compound. She sleeps with her mother until her marriage, while the young boy can very early possess a room of his own. This mindset prevails even today, and when, as a matter of fact, the young girl has a room of her own in her father's house, it is forbidden, in many families, that she speaks of her roogo, out of superstition, so that she may not take roots there, and to invite her to find her true roogo, that is, a husband. [4, p164, translation mine].

Room is simultaneously symbolic of a material building, husband and marriage. To have a room of one's own for a 
woman can mean any of these. Moose people refer to a baby-girl in this context as a "stranger" or passing guest, as she will stay in the family for a time and would later move to live with a husband who will build her a room.

The room or roogo as a material building is placed within a larger unit or compound. The structure of traditional Moose family or compound consists of a cluster of round adobe huts (roogo, plural: roodo) surrounded with an adobe wall. Within the walled area, each family member has a hut or roogo (see figure 1).

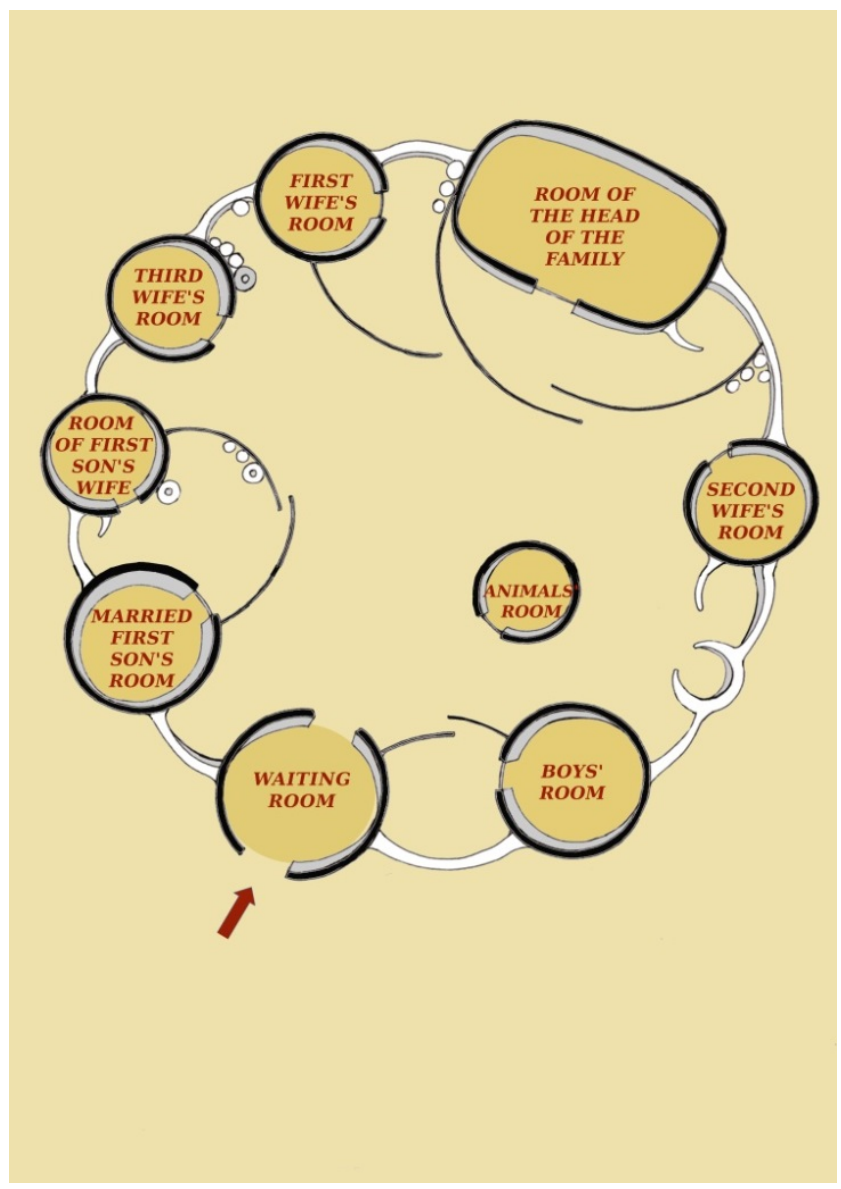

Figure 1. Moose Generic Compound

There is only one room in a round hut. If the head of the family has many wives, each of them has a hut or separate room of her own for herself and her children. It is in her own house that each wife cooks for herself and for her husband and children. If the husband has many wives, he joins each of them for meals in turn. Other huts are used as kitchens, for storage, and as shelter for animals. So, in the Moose tradition, man and woman usually do not sleep in the same room, except for sex. So, in this organization, everybody has his/her own hut except infants and girls who sleep with their mothers.

This traditional structure of the Moose compound is similar to the Igbo's which the Nigerian anthropologist Ifi Amadiume powerfully describes in these lines:

A compound was typically a cluster of huts belonging to individual household units. (...) Homesteads were generally comprised of the houses of a man, his wives, his children, and sometimes his patrilineal cousins. They were often surrounded by mud walls and were nearly always separated from neighboring homesteads by undergrowth or women's gardens. (...) Co-wives had their own rooms, kitchens, and storerooms. Young children and daughters usually stayed with their mothers, whereas the males lived in separate houses." [9].

Adichie is certainly familiar with this situation she does not condone. Her feminism, as well as Ilboudo's, come as a reaction to and rejection of this naturalist conception of African women's being. It is from the vantage point that in both Moose and Igbo traditions, girls comparatively to boys have no hut or room of their own in their parents' compounds that we can understand Ilboudo's and Adichie's feminisms. The fact of not attributing rooms to girls in these cultures is done on purpose to urge them to look for a husband who will build her a room of her own and get married with her.

The similarities of these two West African ethnic groups testify that this organization is a standard one in West Africa. Everything is done in such a way as to engrave in girls' memories that they have to find their own room outside their parents' dwelling place. Adichie [2, p28] in her essay on feminism criticises the fact that the Igbo teach girls to aspire to marriage and not boys. "Because I am female", she writes, "I'm expected to aspire to marriage. I am expected to make my life choices always in mind that marriage is the most important." [2, p28]. She says that her Igbo "society teaches a woman at a certain age who is unmarried to see it as a deep personal failure." [2, p30]. Given this importance of marriage, through which also one acquires a room of one's own, the quest for a room or husband becomes girls' first life objective. So the acquisition of a room of one's own is symbolic of marriage, family, and woman's self-realization. This is a meaning of a room of one's own in the context of African interpretive communities, namely Igbo and Moose ethnic groups. In these communities, a girl's self-realization starts with owning a room. Ilboudo and Adichie challenge that understanding of women in these interpretive communities and the roles they have allotted to men and women.

Reading Woolf's essay with this room symbolism, one notices some similarities. Woolf explains that, having no room of their own then, women sat indoors and became one with the rooms they were in. She uses a strong metaphor in her feminization of room in these terms: "one has only to go into any room in any street for the whole of that extremely complex force of femininity to fly in one's face. How should it be otherwise? For women have sat indoors all these millions of years, so that by this time the very walls are permeated by their creative force." [1, p73]. The room becomes representative of woman as all rooms smell womanish. The girls and infants inside the room are symbolic of babies still in their mothers' wombs. We can 
even say that these creatures stay in their mothers' entrails or rooms until it is time to transfer them to other rooms at the time of their marriage. Woolf continues her powerful metaphoric identification of room with the woman by making bricks and mortar become her writing hands and means [1, p73]. The room being full is also symbolic of pregnancy and creative writing is delivery.

This woman-room relationship is so important that Woolf focuses on it instead of going straight forward into the subject of "women and fiction" which was given to her. At the beginning of her conference, she explains that she was actually asked to speak about women and fiction. But instead, she rather delved on a "room of one's own." She justifies this decision saying that after sitting down on the banks of a river she decided to talk about the importance of money and a room as prerequisite for a woman to become a writer. "A woman must have money and a room of her own if she is to write fiction" has become the famous dictum in her essay. Throughout her essay, as she said herself, she "laid so much stress on money and a room of one's own." [1, p90]. The essay shows "how [she] arrived at this opinion about the room and the money." [1, p4].

Woolf uses the word "room" more than a hundred time in her long essay. Judging from her assertion that she allowed "a generous margin for symbolism, that five hundred a year stands for the power to contemplate, that a lock on the door means the power to think for oneself' [1, p89], one can say that more than standing for a quiet place, the room is symbolically important as shown. It is a metaphor for woman. Insofar as the room stands for a woman, one can understand that when she locks herself she can powerfully think for herself. Hence, Woolf's explanation is that a locked room means the power to think for oneself. She believes that women haven't been able to produce anything worthwhile in the past because they had no privacy and opportunity to really dive into their own thoughts.

Woolf herself is powerfully inspired only when she puts herself into a room setting or environment. In her essay, for example, while answering a question pertaining to comparing two lunch parties, she confides: "And to answer that question I had to think myself out of the room, back into the past $(. .$.$) , and to set before my eyes the model of$ another luncheon party held in rooms not very far distant from these." [1, p11]. This mental gymnastics exercise shows to what extent Woolf's fiction thinking was sometimes room mediated.

She even requires the same condition for her audience made of women, inviting them to find themselves metaphorically in a room-setting in order to fully understand the message she wants to instil into their heads:

"I must ask you to imagine a room, like many thousands, with a window looking across people's hats and vans and motor-cars to other windows, and on the table inside the room a blank sheet of paper on which was written in large letters WOMEN AND FICTION, but no more." [1, p22].
"Room" and "window" are symbolically used. Generally speaking, the room is

"A symbol of individuality-private thoughts. The windows symbolize the possibility of understanding and of passing through to the external and the beyond, and are also the illustration of any idea of communication. Hence, a closed room lacking windows may be symbolic of virginity, according to Frazer, and also of other kinds of non-communication." [10, p274].

In addition to representing the woman's quest for a husband and a family, especially in the West African context, a woman's room refers here to herself. Nadia Julien in Le dictionnaire des symboles adds that a dreamed house with its floors and rooms is often compared to the human body; the bedroom representing intimate life, and the floor, the different parts of the body [11, p214]. These symbolisms recall Sigmund Freud's assertion that "rooms represent women and their entrances and exeunt the openings of the body" and the door key is a male symbol [12]. One can see a parallel of this symbolism in the Moose and Igbo societies. In the Moose ethnic group to which Monique Ilboudo belongs, the house is often associated with the woman; hence housewife and husbands are prohibited to enter their wives' rooms without their consent. Except emergency cases, they go there for sexual intimacy when allowed. Adichie refers to this sexual symbolism through the Nigerian expression of "bottom power" which refers to "woman who uses her sexuality to get things from men." [2, p44]. Thus, in the different societies, there is, generally speaking, a relationship between woman and room. A woman's life is a quest for a room. She finds her life fulfilment once she gets a room of her own. And, to Woolf, a woman becomes a writer once she gets a room of her own and money.

However, and there lies the difference, while women in the African context are fighting for a room, those of Woolf's community wants more than a room. The room should not be "bed-sitting-rooms" [1,p47] but a room with a sitting-room, nor "dark, cramped rooms" [1, p49], nor "the general sitting-room, subject to all kinds of casual interruptions" [1, p56] but "a quiet room or a soundproof room" [1, p44]. In the African context, the room has to be within the homestead whereas Woolf's room of one's own would be preferably an isolated one.

The African women wish that such a room be full of children. Woolf advises women not to have many children or reduce them "in twos and threes, not in tens and twelves." [1, p94]. But Woolf regressively goes far into suggesting childlessness, though she does not hate children. In fact, one can see both in Woolf pointing out that what the four famous women novelists, George Eliot, Emily Brontë, Charlotte Brontë, and Jane Austen have in common is "the possibly relevant fact that not one of them had a child" [1, p56], and in her praising Lady Winchilsea and the Duchess Margaret of Newcastle, saying they are "alike in this that both were noble and both childless," [1, 
p52], that she presents childlessness as an option any career woman should seek. She is thus reacting against the Victorian image of women. In addition, portraying Mary Carmichael and her first novel, Life's adventure, she asserts that "time, money and idleness" [1, p79] are the desirable things a woman should have in addition to having a room. She thinks that multiple births, child rearing, and farming did not leave a lot of room back for women's emancipation. However, members of the African interpretive community see women's alienation in childlessness and idleness. For the latter, women's self-realization cannot be found outside of marriage, families and work. The Burkinabe sociologist Fatoumata Kinda writes that in the past, a woman's blatant laziness constitutes a reason for suing for divorce [13, p221]. It is from the standpoint of this interpretive community that the major differences between Western and African feminism will be highlighted in the follow-up of this room symbolism.

\subsection{Western Feminism versus African Feminism}

Both Ilboudo and Adichie welcome and share the same definition of feminism given in dictionaries, that is, a "doctrine which advocates the expansion of rights, of the role of women in society," which fights to establish social justice and to get rid of gender inequality [4, p163, translation mine). And a feminist is "a person who believes in the social, political and economic equality of the sexes." [2, p47]. Adichie's own definition of a feminist is "a man or a woman who says, 'yes, there's a problem with gender as it is today and we must fix it, we must do better." [2, p48]. She does not restrict feminism only to women's business. She is an example that testifies that "contrary to popular misconception, African feminist statements are neither necessarily anti-Western nor obsessed with duplicating Western feminism." [14, ch8]. Indeed, her feminism is less a response to Western feminism than a contribution to fight for women's political and economic equality. Her feminism is a self-conscious statement on gender.

From these definitions, Ilboudo and Adichie proceed to assert that there have been and will ever be feminists in the African societies. Ilboudo [4, p163] gives the example of some Moose ancestors who fought against the diktat of patriarchy to acquire more social justice for women in the past. Adichie illustrates with the case of her grandmother who "ran away from the house of the man she did not want to marry and married the man of her choice." [2, p47]. Without knowing the word 'feminist', she was already one through her actions. Adichie then recommends the move from "a world in which physical strength was the most important attribute for survival," a thousand years ago, to a different world today in which "it is the more intelligent, the more knowledgeable, the more creative, more innovative" who is "the person more qualified to lead" [2, p17], irrespective of gender. Adichie and Ilboudo invite men and women to work to restore social justice in favour of women.

Yet before giving their own definitions of feminism, Ilboudo and Adichie give the connotation of Western feminism in African societies. They read Western feminism with the strategies of African interpretive community. For example, when people from this interpretive community read this sentence, "you are a feminist" they may understand "you're a supporter of terrorism." [2, p8]. This was actually what Adichie felt when her childhood boyfriend Okoloma first called her a feminist. She did not know the meaning of the word at the time but she knew from the tone of his voice that "it was not a complement" [2, p5]. She had to look up the word in a dictionary, which shows that it is foreign to African everyday parlance.

This terror-inducing word for African people, in the act of reading or hearing it, connotes nothing but unhappiness, un-African, misandry, and marriage destroyer, as can be seen from the following reactions to Adichie's 'feminist' writing. After reading her novel Purple Hibiscus, "a journalist, a nice, well-meaning man" advised Adichie "never to call herself a feminist, since feminists are women who are unhappy because they cannot find husbands." [2, p9]. Then a Nigerian academic woman told her that "feminism was not [their] culture, that feminism was un-African." [2, p9]. Next, a friend dear to her told her that "calling [herself] a feminist meant that [she] hated men." [2, p10]. Then a participant to Adichie's writing workshop advised another one not to listen to her feminist talk "otherwise she would absorb ideas that would destroy her marriage" [2, p25]. These four people-man journalist, academic woman, a friend, and student-constitute samples of African interpretive community and give this community's understanding of Western feminism. Adichie sums up all, saying that, for this community, the

"word feminist is so heavy with baggage, negative baggage: you hate men, you hate bras, you hate African culture, you think women should always be in charge, you don't wear make-up, you don't shave, you're always angry, you don't have a sense of humour, you don't use deodorant." [2, p11].

The negativity in feminism is well expressed in the repetition of the word and phrase "hate" and "don't" and the accusing individual "you" standing against the collectivity and the whole African culture and trying to divest it of all feminine signs to appear angrier, humourless and malodourous.

Loaded with so heavy a luggage, it is difficult for feminism to walk far away from the Western shores. Using this symbolic image of walk, Ilboudo opens her article saying that Western "feminism never flourished in Burkina Faso. Before reaching this Sahelian West African country, the word 'feminism' had walked so long a journey that it was exhausted, faded, and altered." [4, p163, translation 
mine]. It does not flourish because of its heavy-loaded negativity.

As the word "feminism" generally connotes pejorative "Western feminism" in the African interpretive community, many African women reject it [4, p163]. They are even advised to stay away from this movement which can pervert them [4, p168]. In this context where the word "feminism" has become an insult [4, p167], it is understandable that, as Davies observes, "the term 'feminism' often has to be qualified when used by most African and other Third World women." [15, p10]. They refuse to be called "feminist" because people understand a feminist as a parrot of Western feminism.

To avoid this connotation of feminism, many African women's "feminist" identities are qualified with "ifs", "buts", "howevers" or "without", as they do not share all the contents of the heavy-loaded baggage of Western feminism. Ilboudo says that when Burkinabe women who actively work for justice for women are called feminists, they spontaneously correct, adding, "our feminism is a feminism without excess, without violence, without rupture, in the discretion" [4, p176, translation mine] by opposition to their understanding of Western feminism. Likewise, the Nigerian woman writer, Buchi Emecheta, once said that she did not know that by seeing things through an African woman's eyes and chronicling them she was going to be called a feminist. "But if I am now a feminist", she said, "then I am an African feminist with a small f." [16, p 553]. Mariama Bâ too asserts she is not a feminist, at least not in the western sense of the word:

"Not in the western sense. No. Because our problem is beyond feminism. Now, I think our men have an excuse to oppress us because they are not free themselves, even in the so-called independent states. They cannot see that they are being used. So until they are free, you can't really claim to be a feminist." [17, p285].

She rejects the western meaning of the word feminism because it is alien to her situation. Aminata Sow Fall, a prolific Senegalese woman writer, also says she is not a feminist "in the general sense of the word," [17, p287], that is, militant feminism.

Instead of qualifications, such as "if", "small f", "without", "not in this or that sense," other African women use other terms, such as womanism, stiwanism. Flora Nwapa says she is not feminist but womanist. Alice Walker defines a womanist as "a black feminist, or feminist of color."'[18, p xi]. Molara Ogundipe-Leslie advocates "the word 'stiwanism,' instead of feminism, to bypass the combative discourse that ensue whenever one raises the issues of feminism in Africa" [19, p549] to avoid having to respond to charges of imitating Western feminism. "'Stiwa' is [her] acronym for Social Transformation Including Women in Africa" [19, p550]. As Nwangi summarizes,

"the creation of such words as 'Stiwanism' (Ogundipe-Leslie), 'Womanism' (Ogunyemi and Kolawole), 'Kwenu' (Ogunyemi), 'Nego-feminism'
(Obioma Nnaemeka) and 'Motherism' (Catherine Acholonu), 'Uhamili' (Juliana Nfah Abbenyi), and 'Umoja' (Kolawole) to designate African women's understanding of relations between men and women and describe women's movements and struggles are not necessarily total negations of Western feminism. The terms signify the contingency of feminism as it is practised in different parts of the world and Africa." [14, Ch 8].

It is wrong to perceive African feminism in monolithic terms and as a version of Western feminisms. So, although African women writers have travelled in Europe and America, they refuse to be Europeans or Americans or Western feminists but decide to stay African, having their own way of doing things. The very desire to be called feminist with additional qualification into or to resort to alternative terminologies shows that it is necessary to distinguish different forms of feminism. Three main differences will be made explicit by referring to the room symbolism in the feminist discourse of our three writers.

First, the woman's room as womb blessed with children in the African women writers' discourse is opposed to Woolf's isolated sitting-room that would be otherwise perceived by African interpretive community as a cursed room, because lacking children. In fact, Woolf's feminism somehow posits that, women's lives as childbearers and rearers impede literary creativity. Western feminism separates the duties of raising children from those of creative art. The American feminist Sally Bingham complained that her grandmother raised six children while writing and selling stories (Qtd. in [20, p518]. She herself has so far been married to three men successively, has had half of her grandmother's number of children and is a prolific writer. By comparison to her grandmother, she is a feminist. African women, however, are like her grandmother. They do not want to separate childbearing and rearing from creative activity. Woolf's such requirements, Carole Boyce Davies [15, p5] further observes in her "Introduction: Feminist Consciousness and African Literary Criticism", "seem to have no place in the African woman's life." The focus on issues which are of value to African women, such as the respect of their status as mothers, the extended family and polygamy with respect to child care and the sharing of domestic chores constitute the fourth of seven characteristics of a genuine African feminism given by Carole Boyce Davies (1986: 8-10). The African woman is tradition-bound and family-oriented [21, p22]. She has the children in her womb or room, being inseparable from them or it, while doing any other activity.

Contrary to Western feminists, African women see writing as a work like any other and, in their understanding; no work should be an obstacle to procreation by which the woman affirms her femaleness. Alice Walker, in her article on Buchi Emecheta, "A Writer Because of, Not in Spite of, Her Children," explains that African women are culturally mothers and workers by giving the example of Emecheta's creativity which she praises: 
"She integrates the profession of writer into the cultural concept of mother/worker that she retains from Igbo society. Just as the African mother has traditionally planted crops, pounded maize, and done her washing with her baby strapped to her back, so Adah can write a novel with her children playing in the same room." [22, p69].

Childrearing and family chores are traditionally usually seen as normal and becoming women activities and so it is what they do additionally that they consider as work. A woman doing nothing but housework would say she is doing nothing [4, p172]. Adichie tells of a woman who has the same degree and job as her husband. She says that when both are back from work, the woman "does most of the housework, which is true for many marriages," but what struck Adichie was that whenever that woman's husband changed the baby's nappy, she thanked him. [2, p37]. The reason why that woman thanked her husband is that she considers nappy changing or child care in general as her normal and natural duty. In Moose tribe too, cooking was exclusively a woman's occupation to the point that bachelors were ill-fed or were looked after by their mothers [13, p213]. It will take a long time yet for things to change.

For African women, the room is the same for children and for writing workshop. Children sometimes get their participation in this workshop acknowledged. For example, Emecheta dedicated her novel, Second-class Citizen (1994) to her five "dear children Florence, Sylvester, Jake, Christy and Alice, without whose sweet background noises, this book would not have been written." Her fellow African woman writer, Ama Ata Aidoo also gives tributes to her saying, "how can anyone be unimpressed with Buchi Emecheta, who bore five children, struggled to raise them single-handed in a decidedly hostile milieu, and in the years between 1972 and 1984 managed to publish nine novels?" [20, p518]. Both Alice Walker and Ama Ata Aidoo commend Emecheta because she strikes a balance between care for her family and literary creativity. She left her husband at twenty-two with five young children to be cared for. Even though she left her husband, she likes families and continues to take care of her room or family. "In my books I write about families," she says, "because I still believe in families. I write about women who try very hard to hold their family together until it becomes absolutely impossible. I have no sympathy for a woman who deserts her children." [16, p553]. Her writing becomes autobiography, or to use Woolf's image, the extremely complex force of femininity of which the walls of her room are permeated flies in her writing page [1, p73].

Another woman writer, Flora Nwapa, expressing the inseparability between motherhood and other works, says that "the woman writer cannot fail to see the woman's power in her home and society. She sees her economic importance both as mother, farmer, and trader." [18, p529].

Furthermore, whereas barrenness in the symbolism of an empty room can be seen in Western feminism as an incentive to literary creativity and productivity, it is seen by
African women writers as a curse. For African women, through marriage a girl goes into a bare house or room and is blessed there if she fills it with children. Flora Nwapa explains the avalanche of the theme of marriage and barrenness in African women's writings, saying that "the desire to be pregnant, to procreate is an overpowering one in the life of the woman. She is ready to do anything to have a child, be she single or married." [18, p 531]. Moreover, summarizing the strong points made by most African women who hold that feminism is relevant in Africa, Nwapa [18, p549] mentions the fact that "motherhood is idealized and claimed as strength by African women and seen as having a special manifestation in Africa." The denial of children in radical Western feminism stands in opposition to pro-natal African feminism.

In this motherhood-focus context, there is no room in African society for homosexuality as in Western feminism. Ilboudo and Adichie do not make allusion to it in their essays. Yet talking about rearing both boys and girls to virginity and not only girls, Adichie mentions heterosexuality in her comment that "the loss of virginity is a process that usually involves two people of opposite genders" [2, p32]. This difference between Western and African feminisms has been underlined by the American commentator Gwendolyn Mikell when she wrote that "the slowly emerging African feminism is distinctively heterosexual, pro-natal, and concerned with many 'bread, butter, culture, and power' issues." [23, p4]. In the same line, Molara Ogundipe-Leslie [19, p542] also reported that the Federation of Muslim Women of Nigeria (FOMWAN) dislikes feminism because it breeds lesbianism, separates the individuals from collective bonds and trivializes the family. The fact of wanting the woman's room to be quiet of any noise and without children in it is a separation from the collectivity and downplaying the family.

At the opposite of Ilboudo's and Adichie's discourses under study, there are evidences of lesbianism in Woolf's Room of One's Own, which shows that Woolf is a Western feminist. In fact, describing the fiction of Mary Carmichael, Woolf overtly alludes to lesbianism:

"Then may I tell you that the very next words I read were these - 'Chloe liked Olivia...' Do not start. Do not blush. Let us admit in the privacy of our own society that these things sometimes happen. Sometimes women do like women." [1, p69].

It is implied that "these things" are likely to happen in isolated or private rooms and between unmarried women. The African cultural organization provides no idyllic place for carrying out "these things." Hence the heterosexual is a distinctive feature of African feminism. This contextual difference between the two feminisms also shows to a certain extent that individualism and separation from the collectivity can lead to lesbianism or homosexuality which is seen by members of the African interpretive community as "unnatural." 
Linked to this idea of homosexuality is Woolf's theory of the androgynous mind. Androgyny, for her, is a theory that aims to offer men and women the chance to write without consciousness of their sex. This ideal state for a creative mind alternating between male and female has caused contention among critics ever since. Elaine Showalter saw it as an insipid form of homogeneity that "lacks zest and energy." [24, p263]. It is another form of self-sufficient individualism in art. In this theory, male and female do not need each other as each one can become the opposite sex at any time. In the African context, such a theory, especially in reference to the room symbolism, is unsustainable. A man's room and a woman's room are different and separate, and yet complementary. There is no common room that can intermittingly be male's and female's at one's choice.

Second, the woman's room integrated within the compound as opposed to rooms isolated from society, symbolic of collectivity versus individualism, is another major difference between Western and African feminism. Defining Western feminism, the American feminist critic, Katherine Frank says that "feminism, by definition, is a profoundly individualistic philosophy: it values personal growth and individual fulfilment over any larger communal needs or good." [25, p45]. As to African feminism, another American commentator, Gwendolyn Mikell, looking at it from the outside and comparing it to the Western one says that "clearly, it does not grow out of bourgeois individualism and the patriarchal control over women within capitalist industrializing societies. (...) The African variant of feminism grows out of a history of a female integration within largely corporate and agrarian-based societies with strong cultural heritages." $[23, \mathrm{p} 4]$.

The building of huts surrounded by a common wall (fig 1) well expresses this integration of all members within the collectivity. African feminism is then not individualistic. The woman's room is built and integrated within the compound. The woman herself cannot see her self-realization outside her family. As she does not want to fight alone, she can be seen as using polygamy to her advantage by encouraging her husband to have other wives.

The Igbo people in Nigeria and the Moose people in Burkina Faso practise polygamy [26, p28; 4, p172). Of the importance of polygamy, the woman writer Emecheta (2011: 555) says that "in many cases polygamy can be liberating to the woman, rather than inhibiting her, especially if she is educated" because it "encourages her to value herself as a person and look outside her family for friends." [16, p555]. All women have their rooms next to one another, and the husband struts, like a cock between different locations when allowed to enter in. United, they fight for their welfare and that of the family. It is united in common fight that African feminism was born. As Gwendolyn Mikell explains, "African Women's resistance to Western hegemony and its legacy within African culture" has largely shaped African feminism [23, p4]. So, instead of requesting isolated houses to live independently like Western feminists, African feminists fight along with their husbands and children against such acculturation. They hold on to their culture. This communal battle with African men against foreign exploitation constitutes the first of seven characteristics of a genuine African feminism identified by Carole Boyce Davies [15, p8-10].

Third and last, the woman's room with money as opposed to bare room, symbolic of dependence versus resourcefulness, is another major difference between the Western and African feminisms. Virginia Woolf's feminism demands room, money and idleness for women writers. She wishes women possess themselves of "money enough to travel and to idle, ... and loiter at street corners..." [1, p91]. African feminism, however, requires the simple room or husband, regardless of poverty or riches. In The Black Woman Cross-Culturally, Filomina Steady, after comparing Western and African feminism, concludes that women in Africa are practically more feminist than their European sisters: "True feminism is an abnegation of male protection and a determination to be resourceful and reliant. The majority of the black women in Africa and the diaspora have developed these characteristics, though not always by choice." [27, p35-36]. In fact, once the African woman is given a room, she works to be autonomous, spending her day "in general, between the home, the farm, the brook, and the market place" [27, p276) while the Western woman wants a room and money to live in idleness. The praise of African woman's financial self-reliance also features as one of Carole Boyce Davies's seven characteristics of a genuine African feminism. [15, p8-10].

\section{Conclusions}

This paper intends to show the differences between Western feminism and the African one through the room symbolism used by Virginia Woolf and Monique Ilboudo, and to certain extent by Chimamanda Ngozi Adichie. Reading their essays from the lenses of African interpretive community brings about the realization that contrary to African feminisms, the Western correspondent "seems like a mess, a passion, a hysteria, rarely like a reasoned commitment in the political space" [Fraisse qtd in 28, p3, translation mine] and also to the conclusion that one's femininity, or how one is valued as a woman, is inseparable from culture, ethnicity, and education.

Furthermore, genuine African feminism, unlike Western feminism, is a common fight of women alongside men against foreign exploitation, the acknowledgement of certain iniquities in traditional societies, women's financial self-reliance, and the focus on women's issues, such as their lack of choice in marriage, the oppression of barren women, genital mutilations, and the look for possible avenues of choice for women. While the first and second 
generations of African women writers were cautious with the term 'feminism' because of its Western baggage, the third generation to which Adichie belongs conceive feminism differently. As Chielozona Eze shows, they "conceive of their feminism not in opposition to the West, but in relation to it [and sometimes independently from it]. They understand feminism as a moral issue that transcends cultural differences precisely, because it seeks to enhance the dignity of individuals without disrupting community cohesion" [3, ch 2], that is very dear to African people.

Despite their differences, the handling of gender-specific issues and the desire to correct women's second-class status in society remain the common room shared by Western and African feminisms.

\section{REFERENCES}

[1] Woolf, Virginia. A Room of One's Own. E-Book edition. Feedbooks, 1929.

[2] Adichie, Chimamanda Ngozi. We should All be Feminists. London: Fourth Estate, 2014.

[3] Eze, Chielozona. Ethics and Human Rights in Anglophone African Women's Literature: Feminist Empathy. London: Palgrave Macmillan, 2016.

[4] Ilboudo, Monique. "Le féminisme au Burkina Faso: mythes et réalités.” In Recherches féministes 20, n²: 163-177, 2007.

[5] Fish, Stanley. "Interpretive Communties." In Literary Theory: an Anthology, second edition, edited by J. Rivkin and M. Ryan, 217-221. Oxford: Blackwell Publishing, 2004.

[6] Culler, Jonathan. Literary Theory: a very Short Introduction. Oxford: Oxford University Press, 1997.

[7] Barry, Peter. Beginning Theory: An Introduction to Literary and Cultural Theory. Kindle ed. Manchester: Manchester University Press, 2009.

[8] Jackson, Stevi, and Jones, Jackie. "An Introduction to Feminist Theorising". In Contemporary Feminist Theories, edited by S. Jackson and J. Jones, 86-97. Edinburgh: Edinburgh University Press, 1998.

[9] Amadiume, Ifi. 1996. "Igbo." In Encyclopedia of World Cultures. Encyclopedia.com. Online available $<$ http://www.encyclopedia.com $>$. Date of access: 8 September 2016.

[10] Cirlot, J. E. Dictionary of Symbols. New York: Dover Publications, 2002.

[11] Julien, Nadia. Grand dictionnaire des symboles et des mythes. Alleur: Marabout, 1997.

[12] Freud, Sigmund. The Complete Works of Sigmund Freud. Kindle edition. Word Wise Classics, 2016.

[13] Kinda, Fatoumata. "La femme burkinabé: du foyer ménage à la classe ouvrière." In Cahiers du centre de recherché en Lettres, sciences humaines et sociales, 9, 209-233, 1993.

[14] Nwangi, Evan. Africa Writes Back to Self: Metafiction, Gender, Sexuality. New York: Suny Press, 2010.

[15] Davies, Carole Boyce. "Introduction: Feminist Consciousness and African Literary Criticism." in Ngambika: Studies of Women in African Literature, edited by C. B. Davies and A. A. Graves, 1-23. New Jersey: Africa World Press, 1986.

[16] Emecheta, Buchi. "Feminism with a Small 'f'!" In African Literature: An Anthology of Criticism and Theory, edited by T. Olaniyan and A. Quayson, 551-557. Oxford: Blackwell Publishing, 2011.

[17] Adebayo, Aduke. "Feminism in Francophone African literature: from liberalism to militancy. In Francophone African Literature, edited by Oke Olusoka; Ojo, Sam Adeke. 275-298. Ibadan: Spectrum Books Limited, 2000.

[18] Nwapa, Flora. "Women and Creative Writing in Africa." In African Literature: An Anthology of Criticism and Theory, edited by T. Olaniyan and A. Quayson, 526-532. Oxford: Blackwell Publishing, 2011.

[19] Ogundipe-Leslie, Molara. "Stiwanism: Feminism in an African Context." In African Literature: An Anthology of Criticism and Theory, edited by T. Olaniyan and A. Quayson, 542-550. Oxford: Blackwell Publishing, 2011.

[20] Aidoo, Ama Ata. "To Be an African Woman Writer-an Overview and a Detail." In African Literature: An Anthology of Criticism and Theory, edited by T. Olaniyan and A. Quayson, 513-519. Oxford: Blackwell Publishing, 2011.

[21] Mohanty, Chandra Talpade. Feminism without Borders: Decolonizing Theory, Practicing Solidarity. Durham and London: Duke University Press, 2004.

[22] Walker, Alice. In Search of Our Mothers' Gardens. San Diego: Harcourt Brace Jovanovich, pp. 66-70, 1983.

[23] Mikell, Gwendolyn. "Introduction.” In African Feminism: The Politics of Survival in Sub-Saharan Africa edited by G. Mikell, 1-33. Pennsylvania: University of Pennsylvania Press, 1997.

[24] Showalter, Elaine. A Literature of Their Own. London: Virago Press, 1982.

[25] Frank, Katherine. "Feminist Criticism and the African Novel." In African Literature Today 14: 34-48. London: Heinemann, 1984.

[26] Njoku, John Eberegbulam. The Igbos of Nigeria: Ancient Rites, Changes, and Survival. E. Mellen Press, 1990.

[27] Steady, Filomina. The Black Woman Cross-Culturally. Cambridge: Schenkman Publishing Company, 1981.

[28] Riot-Sarcey, Michèle. Histoire du féminisme. Nouvelle edition. Paris: La Découverte, 2008.

[29] Nota Bene: Figure 1 is inspired from CAPES-RGC-B. Etat des lieux des savoirs locaux au Burkina Faso. Sous la coordination de J. B. Kiéthéga. Ouagadougou: no publisher, 2006, p. 129. 